\title{
ALBERT TAKÁCS
}

\section{Election campaign in the Antiquity ${ }^{* *}$}

The volume "How to Win Elections? Quintus Tullius Cicero: Handbook for Applicants for Offices" by György Németh and Tamás Nótári ${ }^{1}$ and the monograph "Law, Religion and Rhetoric" by Tamás Nótári ${ }^{2}$ are not only professional works written for jurists of Roman law and historians of the Antiquity. The works of historian György Németh and jurist/philologist Tamás Nótári makes the oldest campaign strategy manual available to readers in Hungarian, and attaches ample commentaries and notes, after word and accompanying study thereto, from which we can develop an exact picture of the election system of the Republic of Rome, the methods of election campaign of the period, the state of facts of election abuses and the sanctions applied to them. All these are issue that may deservedly attract the attention of readers engaged in jurisprudence, interested in public and criminal law.

One of the most famous orators of the Antiquity, Marcus Tullius Cicero entered the election for the consul's position held in 64 B.C. arranged under extremely disturbed circumstances and he won the consulatus for 63 B.C. Difficulties were caused among others by the fact that an indebted nobleman called Lucius Sergius Catilina saw the only breakthrough for ensuring his

* Professor, Corvinus University of Budapest, Faculty of Public Administration, H-1118 Budapest, Ménesi út 5.

E-mail: albert.takacs@uni-corvinus.hu

** The present review is the written version of the presentation of books held in the Reviczky-Castle in Magyarnándor-Kelecsény on the $18^{\text {th }}$ September 2008 organised by the Hungarian Official Journal Publisher.

${ }^{1}$ Hogyan nyerjük meg a választásokat? Quintus Tullius Cicero: A hivatalra pályázók kézikönyve. Fordította, a jegyzeteket, az előszót és az utótanulmányt írta Nótári Tamás. Szerkesztette és a kísérő tanulmányt írta Németh György (How to Win Elections? Quintus Tullius Cicero: Handbook for Applicants for Offices. Translation, preface, notes and after word by Tamás Nótári. Ed. and accompanying study by György Németh). Szeged, Lectum, 2006. 156 pp.

${ }^{2}$ Nótári, T.: Jog, vallás és retorika (Law, Religion and Rhetoric). Budapest, Magyar Közlöny Lap és Könyvkiadó, 2008. 356 pp. 
political and financial survival in being elected consul, and manifested that in case he would lose he would be willing to take as well violent actions (later, he actually carried out his threats). The orator's younger brother, Quintus Tullius Cicero wanted to help his brother in his campaign foreseen as having quite a lot of turns; so, he wrote a manual for him on the lawful and illegal instruments that could be used in the elections. This work, Commentariolum petitionis (A Handbook for Applicants for Offices) is the first summary of campaign strategy in the history of mankind. In addition to the evaluation of the given situation, the presentation (and exploitation) of the weaknesses of counter nominees, the book provides advice on several counts that might possibly continue to have relevance even today.

In the opening lines and in the last paragraph of Commentariolum, Quintus Tullius Cicero addresses his brother, Marcus in a fairly close, brotherly manner, and at the end of the letter he asks him to share his comments on this writing with a view to adding or correcting things so that later on the work could be made public as a real little manual. Nótári asserts that it is not probable that after Marcus had reviewed and revised it Quintus published this work, in which he outlines the ways of organising and conducting the election campaign since he explores the stages of the fight for votes with merciless frankness. The exploration of uninhibited opportunism and manoeuvring must have been far from being in the interest of the ruling classes in the age of the late phase of the Republic, and especially, it would have put Marcus Tullius Cicero himself in an unpleasant situation-as he would not have been able to remove himself from the suspicion of having won the consulatus for no other reason than that he had used all these instruments in practice.

The Republic of Rome recognised four kinds of popular assemblies; three of them played a part in the elections. The so-called comitia centuriata based on property census elected the prime leaders of the Empire, the consules and the praetores who carried out administration of justice as well as the censores who implemented property estimation. The point of the system was that based on their property status, income the population was ranked among military/political centuriae. The centuriae of the wealthier as a matter of fact did not amount to one hundred persons while the number of persons in a single centuria of the pauper was at least as large as the whole first class; that is, the total of the eighty centuriae of the aristocracy. Equites constituted eighteen centuriae. The wealthier the people recruited were, the higher the number of centuriae was; i.e., the number of citizens classified in each centuria was steadily increasing when the given centuria consisted of less and less wealthy people. Through that it was possible to attain that people without any property were represented only by five centuriae. 
Elections were held in a process per centuriae-and "from up to down". This means that first wealthier people cast their vote and after that the poorer, finally the pauper, who constituted the major part of the population. Although the ballots cast by each citizen were equal but their ballots were aggregated per centuria and their centuria eventually represented only a single 'yes' or 'no' vote, depending on which response the majority of the ballots was cast in the centuria. If a case had to be decided or an official had to be voted for, voting was carried out only up to the stage where the centuriae that had already cast their vote had reached fifty percent plus one ballot. As the eighty votes of the eighteen votes of the equites and the eighty votes of the first class of the patricians/the aristocracy themselves were more than half of the one hundred and ninety-three centuriae in total, it can be clearly realised that even the twenty centuriae of the second property class had to cast their ballots only in the very rare case that the centuriae of the knights and the first class had not reached accord for some reason. As, however, the first ninety-eight centuriae actually represented merely a fraction of the whole of the citizens, the election was far from reflecting the will of the majority of the citizens.

The day of the election of the consuls always fell on the second half of July. The electors went out to the Mars field early morning and gathered by centuriae. The persons controlling the elections announced the names of the candidates; and, after that voting began. The identity of the voters appearing per centuriae was verified by the guards at the gateway to the voting bridge. Voters wrote the initials of the name of the candidate they supported on a wax covered piece of wooden board. At the other end of the voting bridge a ballotbox was set up where they cast their boards. Once one centuria has cast their votes, ballots were aggregated in the ballot counting chamber, and the names of the candidates were written in a predetermined order, with the decisions of the centuriae added beside the names. When a candidate had reached fifty percent plus one vote of the ballots of the centuriae, voting was discontinued, and the result was proclaimed.

The institution of campaign silence was unknown to the Romans since agents tried to convince voters to vote for specific candidates even at the gate of the bridge. If it was foreseen that the result would be unfavourable for patricians, then the voting bridge collapsed "accidentally", and the voting had to be interrupted-and be postponed for several days. Then, in some cases, augures showed up, who stated that they were seeing ill omina, and this allowed declaring the whole procedure null and void.

As a matter of fact, it was much easier to influence voters efficiently during the campaign. Election announcements are still available to us-painted on the plaster of the walls in Pompeii that have been preserved by volcanic ash and 
lava. These announcements were produced by a special branch of industry; first white washers worked, who primed the wall; then, scriveners painted the text of the announcement on the "poster prime". Sometimes they initialled these announcements, and it can be known from this that often the same advertising company offered its services to two opposing parties. Election "posters" include items with both positive and negative content.

The person who summed up campaign strategy for the first time was Quintus Tullius Cicero, the younger brother of the famous orator who summed up his advice in his work Commentariolum petitionis in 64 B.C., which were then addressed to Marcus Cicero, who applied for the position of consul, i.e., the highest state office. In addition to the evaluation of the given situation, presentation (exploitation) of the weaknesses of the opponents, the book provides advice on several counts, which possibly continue to have relevance even today.

The first thing he advised was to determine the strategic objective exactly: he should think it over in what state he was living; what he was applying for; and in what situation he was. It is important in the advice that the candidate-in this case Marcus Tullius Cicero-should rely on his young students since, in Quintus's view, the election will be won by the candidate who manages to get youth to stand by him, and he should build on everybody whom he had successfully defended in court as an advocate. He provided advice also on how to discredit political opponents: one of them had purchased his mistress on a slave market, the other was living in an incestuous relation with his own elder sister and had had noble knights killed. Even if all this was not completely true, it served to compromise them.

Even more important than discrediting opponents is to win as many friends as possible. It is important to appear in the company of popular people, even if they do not support the candidate since those who can see them together will not necessarily know that. Quintus lists three kinds of ways of how to arouse sympathy: when one does good to somebody; when people hope that we will do good to them, or when people likes us. One should send the message to the friends of our friends that one will not be ungrateful if they support us. One should promise them offices since the worst that could happen is that we might possibly not keep our promise once having won the consul's office. The most important thing, however, is that when one appears in a village, everybody who counts must be called by their name. "Village folks-writes Quintus cynicallywill immediately imagine themselves our friends if we know their name."

It is important to appear in the company of popular people, even if they do not support the candidate since those who can see them together will not necessarily know that. Quintus lists three kinds of ways of how to arouse 
sympathy: when one does a favour to somebody; when people hope that we will do a favour to them, or when people likes us. One should send the message to the friends of our friends that one will not be ungrateful if they support us. One should promise them offices since the worst that could happen is that we might possibly not keep our promise once having won the consul's office. Quintus asserts that a candidate should keep the map of entire Italy in his mind so that there should be no village where he has no sufficient support. Each electoral district should be covered by a web of friendly relations. The most important thing, however, is that when one appears in a village, everybody who counts must be called by their name. However, so many names to keep in mind is an impossible task for anybody. To this end, nomeclatores (name reminders) were used, who whispered who was who into one's ears. In Quintus Cicero's view, to contact those who are hesitating between political sides three things are needed: generosity, attention and, occasionally, some pretension and flattery, "since a candidate should every time adjust to those whom he just meets." One should let everybody to have access to him day and night; everybody should be helped; or at least one's help should be promised but all this in such manner that one does not hurt self-esteem of those whom one helps.

From all this it can deduced-in spite of Quintus Cicero not uttering it word for word-that in order to obtain the given office a candidate should not be afraid of using any tricks, making false promises, telling lies, using pretension and getting close to the group that seems appropriate for the purpose.

After analysing the campaign strategy, Nótári returns to the state of facts of election fraud/bribery, the so-called ambitus, and demonstrates that as early as after the Twelve Table Law it was sanctioned if candidates called voters' attention to themselves by wearing specially whitened clothes. There must have been little effect produced by this provision since it is on the grounds of whitened clothes, the toga candida that nominees are still called candidates (candidati). In the Roman terminology only ambitus was in conflict with law; whereas ambitio (winning voters' mercies through ways that can be considered unacceptable in terms of ethic but not in terms of law) did not. This was often applied as a term interpreted as the act of obtaining votes; its meaning was sometimes undoubtedly pejorative but it had never become a legal technical term-the borderline between the two terms, however, was never clear cut. Later, laws punished candidates who violated the fairness of the elections by being exiled, imposing a fine and losing the right of being elected; so, for example, actual bribery, holding large feasts, distributing complimentary tickets to theatre performances and gladiators' games, etc. The author, however, might be right when having analysed several cases he asserts that the actual limits of election abuses were restricted only by the financial possibilities of candidates. 
We do not know to what extent the experienced politician, Cicero adhered to his younger brother's advice; it is, however, a fact that he was elected consul, and as a consul he defeated Catilina's revolt in. 63 B.C. This volume is interesting not only for historian of the Antiquity and jurists of Roman law since the work written with profound scientific erudition and the precise translation conveys the picture of a colourful world exciting to people of the present day. Finally, to illustrate this, a few sentences from the election advice, campaign tricks provided by Quintus Tullius Cicero, also quoted in the dust jacket comments of the volume, follow: "People living in the provinces and village folks will immediately imagine that they are our friends if we know their name. Acquire the skill that is not yours from nature: you should pretend to make your acts appear natural! - (The candidate) should shape and adjust his countenance, look and speech to the way of thinking and will of all those whom he meets. - Do not let that there should be a single provincial town, a single settlement, a single local authority or any place where you do not have sufficient support! You must have a plan that covers the whole town, each territory, district and neighbourhood! - Attain that your (competitors) should know that you supervise and watch them! - Make sure that the whole procedure of candidacy should be pompous, bright, gleaming and kind to the people, and should be fairly striking, ... and that the sentence condemning the way of life of your competitors should be spread! - Attain that all those who you hold in your hands as people committed to you, should have tasks clearly determined and allocated! - In the procedure of candidacy special attention must be paid to achieving that the State should entertain good hopes and respectful opinion towards you; yet, you must not appear to be ... thirsty of power. - And the masses should think that you will work for their benefit!" 